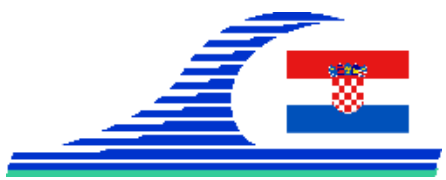

\author{
Conférence Méditerranéenne Côtière et Maritime \\ EDITION 4, SPLIT, CROATIA (2017) \\ Coastal and Maritime Mediterranean Conference

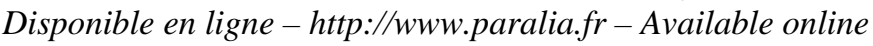

\title{
Variation of the 1.5 ka surface water marine radiocarbon reservoir age in the Adriatic based on the study of algal rims
}

\author{
Sanja FAIVRE ${ }^{1}$, Tatjana BAKRAN-PETRICIOLI ${ }^{2}$, Jadranka BAREŠIĆ ${ }^{3}$, \\ Christophe MORHANGE ${ }^{4}$, Damir BORKOVIĆ ${ }^{3}$, Davor HORVATIĆ ${ }^{5}$
}

1. University of Zagreb, Faculty of Science, Department of Geography, Marulićev trg 19/II, 10000 Zagreb, Croatia.

sfaivre@geog.pmf.hr

2. University of Zagreb, Faculty of Science, Department of Biology, Rooseveltov trg 6, 10000 Zagreb, Croatia.

3. Ruđer Bošković Institute, Radiocarbon Laboratory, Bijenička 54, 10000 Zagreb, Croatia.

4. Université Aix-Marseille, CEREGE UMR 7330, Institut Universitaire de France, Europôle de l'Arbois, BP 80, 13545 Aix-en-Provence cedex 04, France.

5. University of Zagreb, Faculty of Science, Department of Physics, 10000 Zagreb, Croatia.

\begin{abstract}
:
The latest research on relative sea-level change along the eastern Adriatic has been cantered on algal rims build by Lithophyllum byssoides (FAIVRE et al., 2010; 2013). Such fossil bio-constructions have proven to be precise sea-level indicators in microtidal environments (LABOREL et al., 1994). However, this perfect relative sealevel marker is constrained by its marine radiocarbon reservoir age (MRE) which is not known. Previous research assumes that Lithophyllum does not appear to be subject to any kind of reservoir effect. Those assumptions were based on the datation of living thalli (LABOREL et al., 1994). Here, we provide evidence for the algal MRE based on algal samples of known age obtained from the Natural History Museums in Paris and Vienna and from the Universität Hamburg. The algae used for ${ }^{14} \mathrm{C}$ dating were collected from AD 1858 to 1913 and represent the pre-bomb period. We applied radiocarbon dating of marine material with a known calendar date of death of the organism. This approach enables a comparison of contemporaneous atmospheric and marine radiocarbon ages. The deficiency in ${ }^{14} \mathrm{C}$ content of the measured marine sample relative to the global atmospheric calibration curve is then used to calculate the "apparent age" of the material. We further used palaeo data from 10 Eastern Adriatic algal rims from which we obtained radiocarbon and stable isotope $\left(\delta^{18} 0\right.$ and $\left.\delta^{13} \mathrm{C}\right)$ records. Based on those records we provide several lines of evidence that the alga which lives in the intertidal zone has a lower marine radiocarbon reservoir age than the mean surface water MRE. On the other hand, shells (mytilid bivalves) from algal rims reveal higher
\end{abstract}


Mediterranean rocky coasts:

Features, processes, evolution and problems

reservoir ages than global means, similar to previously published data (FAIVRE et al., 2015).

Furthermore, as living exclusively in the intertidal zone $L$. byssoides, could reflect longterm surface water MRE variations as surface ocean radiocarbon time series can provide a unique opportunity to study both air-sea ${ }^{14} \mathrm{CO}_{2}$ exchanges and ocean circulation dynamics.

Till now continuous marine ${ }^{14} \mathrm{C}$ records have only been acquired from a limited number of biogenic calcifying archives. Currently, only sparse ${ }^{14} \mathrm{C}$ data are available for the Mediterranean Sea in order to constrain the MRE with limited age ranges (SIANI et al., 2000, 2001; REIMER and MCCORMAC, 2002; MCCULLOCH et al., 2010; TISNÉRAT-LABORDE et al., 2013; FAIVRE et al., 2015). In this framework, several research lines on algal and shell MREs (shells inhabiting algal rims) have been initiated, which could together provide records on MRE variability throughout the 1.5 ka period. Our radiocarbon and stable isotope records over the last $1.5 \mathrm{ka}$ from 10 algal rims revealed bimodal properties of the Adriatic surface water MRE.

\section{Keywords:}

Algal rims, Bioconstructions, Lithophyllum byssoides, Marine radiocarbon reservoir age, Adriatic, Mediterranean.

\section{Acknowledgements}

This research was supported by the Croatian Science Foundation (project no. HRZZ-IP11-2013-1623, Reconstruction of the Quaternary environment in Croatia using isotope methods - REQUENCRIM) and by the University of Zagreb Supports for 2013 (no. 4.1.1.28), 2014 (no. IP2.4) and 2015 (no. IP003). We would also like to express our gratitude to the Muséum National d'Histoire Naturelle in Paris, especially to Bruno de Reviers, for providing algal samples from its collections for this research. We also thank the Universität Hamburg, Biozentrum Klein Flottbek und Botanischer Garten, Dr Matthias Schultz (curator at Herbarium Hamburgense) as well as the Naturhistorisches Museum, Wien, Dr Anton Igersheim (Curator of the Cryptogamic Collection) both of which kindly provided samples without which this study could not be effectuated.

\section{References}

FAIVRE S., BAKRAN-PETRICIOLI T., HORVATINČIĆ N. (2010). Relative sea-level change during the late Holocene on the island of Vis (Croatia) - Issa harbour archaeological site. Geodinamica Acta, 23/5-6, pp. 209-223. http://dx.doi.org/10.3166/ga.23.209-223

FAIVRE S., BAKRAN-PETRICIOLI T., HORVATINČIĆ N., SIRONIĆ A. (2013). Distinct phases of relative sea level changes in the central Adriatic during the last 1500 
Mediterranean rocky coasts:

Features, processes, evolution and problems

years - influence of climatic variations? Palaeogeography, Palaeoclimatology, Palaeoecology, 369, pp. 163-174. https://doi.org/10.1016/j.palaeo.2012.10.016

FAIVRE S., BAKRAN-PETRICIOLI T., BARESIC J., HORVATINCIC N. (2015). New data on the marine radiocarbon reservoir effect in the Eastern Adriatic based on pre-bomb marine organisms from the intertidal zone and shallow sea. Radiocarbon, Vol. 57 (4), pp. 527-538. https://doi.org/10.2458/azu_rc.57.18452

LABOREL J., MORHANGE C., LAFONT R., LE CAMPION J., LABORELDEGUEN F., SARTORETTO S. (1994). Biological evidence of sea-level rise during the last 4500 years on the rocky coasts of continental southwestern France and Corsica. Marine Geology, 120, pp. 203-223. https://doi.org/10.1016/0025-3227(94)90059-0

McCULlOCH M., TAVIANI M., MONTAGNA P., LOPEZ-CORREA M., REMIA A., MORTIMER G. (2010). Proliferation and demise of deep-sea corals in the Mediterranean during the Younger Dryas. Earth and Planetary Science Letters, 298, pp. 143-152. https://doi.org/10.1016/j.epsl.2010.07.036

REIMER P. J., McCORMAC F. G. (2002). Marine radiocarbon reservoir corrections for the Mediterranean and Aegean seas. Radiocarbon, Vol. 44 (1), pp. 159-166.

https://doi.org/10.1017/S0033822200064766

SIANI G., PATERNE M., ARNOLD M., BARD E., METIVIER B., TISNÉRAT N., BASSINOT F. (2000). Radiocarbon reservoir ages in the Mediterranean Sea and Black Sea. Radiocarbon, 42(2), pp. 271-280. https://doi.org/10.1017/S0033822200059075

SIANI G., PATERNE M., MICHEL E., SULPIZIO E., SBRANA A., ARNOLD M., HADDAD G. (2001). Mediterranean sea surface radiocarbon reservoir age changes since the last Glacial Maximum. Science, 294, pp. 1917-1920. doi: 10.1126/science.1063649 TISNÉRAT-LABORDE N., MONTAGNA P., MCCULLOCH M., SIANI G., SILENZI S., FRANK N. (2013). A high-resolution coral-based $\triangle 14 C$ record of surface water processes in the western Mediterranean sea. Radiocarbon, Vol. 55 (2-3), pp. 16171630. https://doi.org/10.1017/S0033822200048530 
Mediterranean rocky coasts:

Features, processes, evolution and problems 